
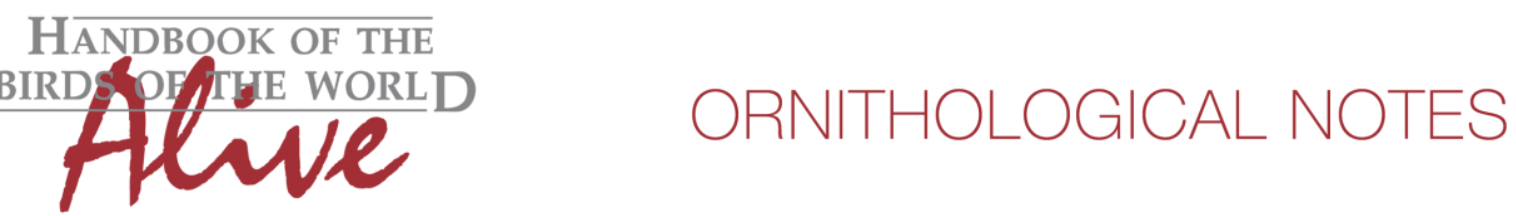

\title{
Notes on the vocalizations of Undulated Antshrike (Frederickena unduligera)
}

Peter Boesman

In the following we briefly analyze and compare voice of the different races of Undulated Antshrike (Frederickena unduligera). We also try to quantify the extent of any vocal differences using the criteria proposed by Tobias et al. (2010), as a support for taxonomic review. We have made use of sound recordings available on-line from Xeno Canto (XC).

Voice has been analyzed in detail by Isler et al. (2009). Main differences in loudsong between fulva and other races are said to be note shape, pace and rising frequency towards end, supported by data. Average value and standard deviation for the latter two are given, thus effect size can be calculated:

pace

fulva (av. $2.89 \mathrm{sd} 0.3$ notes/s, $n=11$ ) vs other races (av. $4.27 \mathrm{sd} 0.46$ notes $/ \mathrm{s}, n=16$ ) -> effect size 3.55 -> score 2

rising end (expressed as a frequency ratio)

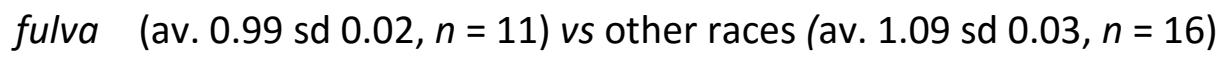

-> effect size 3.9 -> score 2

This results in a total score of 4 .

Note shape of fulva is described as upslurred whereas notes of the other populations as rounded into an inverted $U$. At least in some cases the difference is less striking than the sonograms in the paper suggest. fulva can also have overslurred notes from the 3rd or 4th note onwards, see e.g. XC77039, XC69889 and XC56726 being somewhat intermediate. While note shapes here are less nicely rounded inverse ' $U$ ' than examples of other races, difference in note shape in these particular cases becomes really minor (Fig.1). This could be given therefore at most a score 1. 


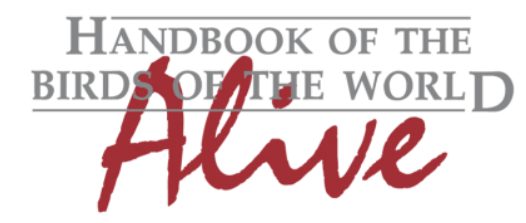

\section{ORNITHOLOGICAL NOTES}
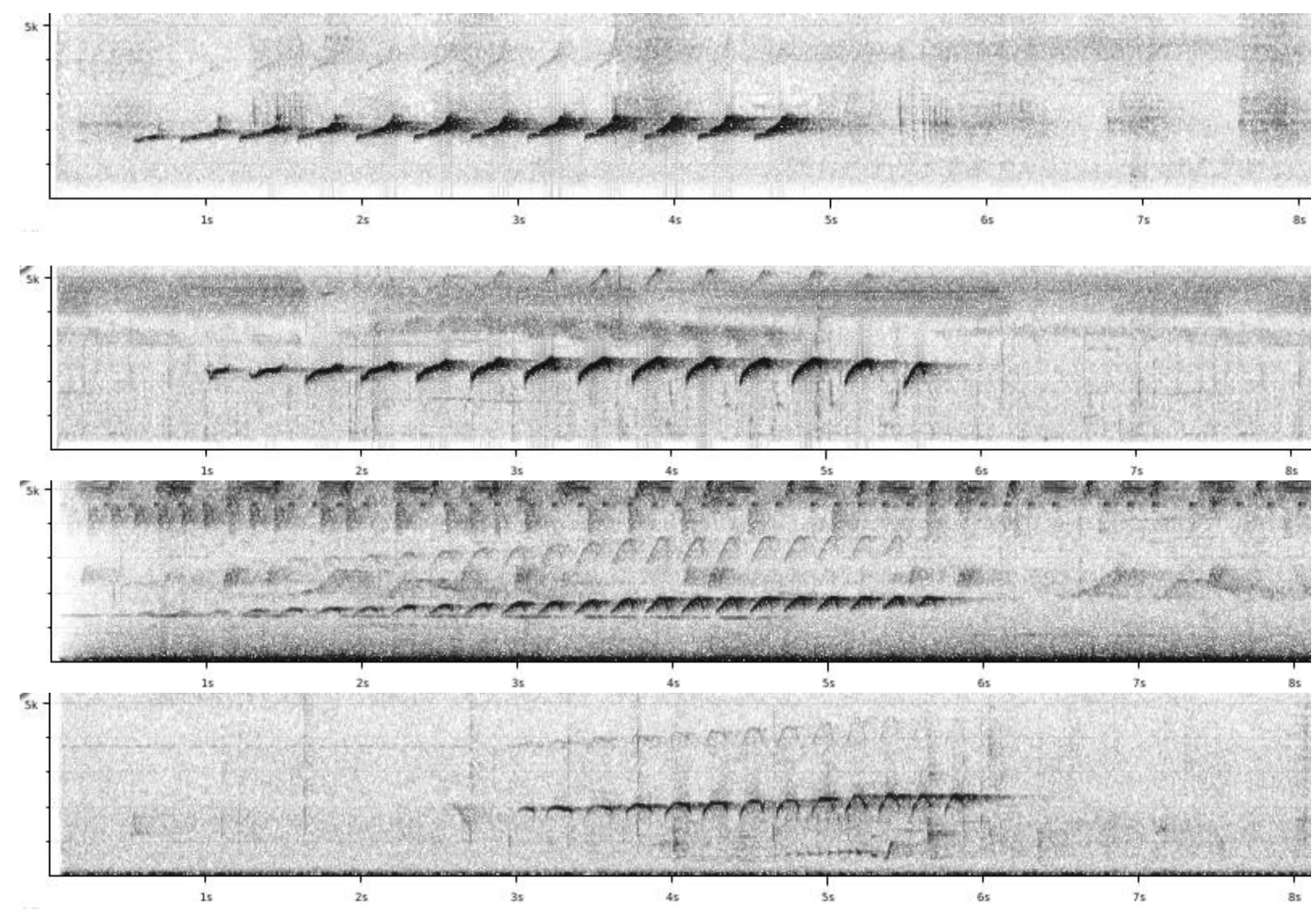

Figure 1: Top to bottom: typical example of upslurred notes in fulva, less upslurred in fulva and typical example of other races resp. diversa and unduligera.

All in all, we can conclude that the vocal differences of fulva vs other races in loudsong are a slower pace (2) and nearly flat pitch in the second half of the song (2). Notes are generally upslurred (1).

This note was finalized on 30th April 2015, using sound recordings available on-line at that moment. We would like to thank in particular the sound recordists who placed their recordings of for this species on XC: Peter Boesman, Tayler Brooks, David Geale, Frank Lambert, Daniel Lane, Niels Krabbe, John V. Moore, Alexandre Renaudier, Andrew Spencer and Charlie Vogt.

\section{References}

Isler, M. L., Isler, P. R., Whitney, B. M., Zimmer, K. J., and Whittaker, A. 2009. Species limits in antbirds (Aves: Passeriformes: Thamnophilidae): an evaluation of Frederickena unduligera (Undulated Antshrike) based on vocalizations. Zootaxa 2305: 61-68.

Tobias, J.A., Seddon, N., Spottiswoode, C.N., Pilgrim, J.D., Fishpool, L.D.C. \& Collar, N.J. (2010). Quantitative criteria for species delimitation. Ibis 152(4): 724-746. 


\section{Recommended citation}

Boesman, P. (2016). Notes on the vocalizations of Undulated Antshrike (Frederickena unduligera). HBW Alive Ornithological Note 51. In: Handbook of the Birds of the World Alive. Lynx Edicions, Barcelona. (retrieved from http://www.hbw.com/node/931930 on 30 April 2016). 